\begin{tabular}{c} 
NANAEKE \\
$\begin{array}{c}\text { Indonesian Journal of Early Childhood Education } \\
\text { Volume 3, Nomor 2, Desember } 2020\end{array}$ \\
\hline
\end{tabular}

\title{
VALIDITAS PANDUAN PERMAINAN KONTEKSTUAL UNTUK ANAK USIA DINI
}

\author{
Tri Ayu Lestari Natsir \\ Program Studi Pendidikan Islam Anak Usia Dini \\ Fakultas Tarbiyah dan Adab, Institut Agama Islam Negeri Parepare \\ E-mail:triayulestari17@gmail.com
}

\begin{abstract}
Abstrak
Tujuan penelitian ini adalah untuk menghasilkan panduan permainan untuk anak usia dini yang valid. Penelitian ini dilakukan di kelompok B TK Buah Hati Makassar. Metode yang digunakan dalam penelitian ini adalah penelitian dan pengembangan.Pada penelitian ini akan dijelaskan secara rinci uji validasi isi dari panduan tersebut. Validasi isi dilakukan oleh dua orang professional Judgement.Validasi panduan permainan untuk anak usia dini di kelompok B dinyatakan valid pada aspek komponen dengan nilai 3,5, aspek format dengan nilai 3.2, aspek isi dengan nilai 3.4, aspek bahasa dan tulisan 4.0. Validasi panduan pembelajaran untuk anak usia dini dinyatakan sangat valid pada aspek ilustrasi, tata letak tabel dan diagram dengan nilai 2.9 dangan aspek manfaat buku dengan nilai 3.5. Untuk nilai rata-rata total kevalidan panduan permainan untuk anak usia dini di kelompok B $\overline{\boldsymbol{x}}=\mathbf{3 . 4 6}$, sehingga panduan tersebut dapat dikatakan memenuhi kriteria kevalidan.
\end{abstract}

Kata Kunci: Panduan Permainan, Anak Usia Dini, Validasi Isi

\begin{abstract}
This study aimed to produce valid playing guidance for early childhood. This research was in group B TK Buah Hati Makassar. This research was development research that explains in detail the content validation of the product. The content was validated by two professional validators. The validation of the playing guidance for early childhood in group $B$ was met valid category on the component aspect with a value of 3.5, the format aspect with a value of 3.2, the content aspects with a value of 3.4, language, and writing aspects with a value of 4.0. While on the aspects of illustration, tables, and diagrams layout met the very valid category with a value of 2.9. The aspects of the benefits of the product met a valid category with a value of 3.5. The total average value of the validity of playing guidance for early childhood in group $B$ was $B \overline{\boldsymbol{X}}=\mathbf{3 . 4 6}$ so that the guide met the validity criteria.
\end{abstract}

Keywords: Playing Guidance, Early Childhood, Content Validation

\section{PENDAHULUAN}

Pendidikan pada dasarnya mempunyai tujuan dan sasaran untuk mengembangkan setiap potensi yang dimiliki oleh manusia, hal ini pun tidak terlepas dari proses 
pendidikan untuk anak yang pada dasarnya tidak dapat dipisahkan dari lingkungan tempat anak tumbuh dan berkembang. Pendidikan memiliki peran yang sangat penting di masa kanak-kanak, karena perkembangan kepribadian, sikap mental, intelektual, dan sosial dibentuk pada usia dini. Dunia anak adalah dunia bermain, setiap ada kesempatan dimanapun dan kapanpun selalu bermain dengan belajar sambil bermain anak merasa bahagia dan ceria. Bermain adalah kegiatan yang mereka lakukan sepanjang hari karena bagi anak bermain adalah hidup dan hidup adalah permainan. Melaui bermain anak akan mencoba, merasakan, mencari, menemukan, sehingga diperoleh sesuatu yang baru dari aktivitas dalam bermain. Bermain yang dilakukan dalam kegiatan pembelajaran tidak hanya disukai oleh anak-anak, tetapi juga sangat bermanfaat bagi perkembangan anak, yang meliputi manfaat motorik, manfaat afeksi, manfaat kognitif, manfaat spritual, dan manfaat keseimbangan.

Pembelajaran di Taman Kanak-kanak berpedoman pada prinsip belajar sambil bermain atau bermain sambil belajar (Depdiknas, 2004). Bermain merupakan tuntutan dan kebutuhan bagi anak usia dini di Taman Kanak-kanak, sehingga kegiatan pembelajarannya dilakukan dengan berbagai macam permainan dalam suasana yang menyenangkan dan merangsang anak untuk terlibat secara aktif.

Abdullah (2004) mengemukakan bahwa pada dasarnya pengembangan program pembelajaran adalah pengembangan sejumlah pengalaman belajar melalui kegiatan bermain yang dapat memperkaya pengalaman anak tentang berbagai hal, seperti cara berpikir tentang diri sendiri, tanggap pada pertanyaan, dapat memberikan argumentasi untuk mencari berbagai alternative.Dalam bermain aktif, kesenangan timbul dari apa yang dilakukan individu, apakah dalam bentuk kesenangan berlari atau membuat sesuatu dengan lilin atau cat. Dalam bermain pasif kesenangan diperoleh dari kegiatan orang lain. Kegiatan yang melibatkan banyak aktivitas tubuh atau gerakan-gerakan tubuh.

Pada masa anak-anak, bermain sangat bermanfaat pada anak itu sendiri. Karena sangat berpengaruh pada aspek perkembangan baik perkembangan kognitif, sosial, motorik, bahasa, seni, nilai moral agama. Bermain juga berfungsi sebagai penyalur tenaga yang berlebihan yang bila terpendam terus akan membuat anak tegang, gelisah, dan mudah tersinggung.

Salah satu yang menunjang keberhasilan pembelajaran di taman kanak kanak adalah penyediaan sarana yang dibutuhkan, yakni bahan ajar. Bahan ajar merupakan asal muasal pembelajaran yang dapat menolong pendidik agar mampu menciptakan transformasibudi pekerti anak didik menjadi lebih baik sesuai dengan apa yang diharapkan. Bahan ajar memiliki peran yang krusial terhadap proses belajar mengajar. (Lasmiyati \& Harta, 2014).

Panduan adalah penyusunan bahan ajar secara sistematis dengan tata bahasa yang yang gampang dimengerti agar anak didik mampu menerima materi di 
kelas dengan baik (Prastowo, 2012). Panduan juga dapat diartikan sebagai suatu paket dalam program yang dirancang dan didesain dengan khusus untuk keperluan dalam proses belajar anak didik. Pendekatan yang digunakan dadalah menggunakan pengalaman anak didik sebelumnya (Susilana \& Riyana, 2008).

Pada prinsipnya tujuan pembelajaran adalah agar anak didik mampu memahami materi sesuai dengan indikator yang telah dibuat. Hal tersebutdikarenakan dalah suatu kelasterdapat anak didik dengan potensi yang berbeda baik itu dari segi bakat,kecerdasan, maupun kecepatan belajar. Oleh karena itu perlu diadakan pengelompokan materi pembelajaran, sehingga semua anak didik bisa menguasai seluruh indikator pelajaran sesuai dengan apa yang diharapkan dan waktu yang sudah ditetapkan. Selain pengolompokan materi pembelajaran, yang juga perlu menjadi perhatian adalah cara mengajar yang sesuai dengan seluruh karakteristik anak didik yang ada di kelas.Cara pelaksanaan pembelajaran tersebut adalah dengan memisahkan bahan pembelajaran tersebut menjadi bagian yang lebih kecil (satu atau lebih pokok bahasan). (Sirate \& Ramadhana, 2017).

Panduan adalah suatu bahan belajar bisa digunakan oleh anak didik dengan cara yang independen. Sebuah panduan dapat dikatakan baik ketika disusun secara jelas, menarik, dan sistematis. Panduan bisa digunakan kapan saja dan dimana saja berdasarkan kebutuhan anak didik. Panduan merupakan bahan ajar yang dirancang secara menarik dan terstruktur yang bisa digunakan secara individu untuk mencapai standar kompetensi dengan karakteristik panduan pembelajaran antara lain: 1) Self instructional, anak didik bisa independen, mampu mengandalkan diri sendiri; 2) Self contained, mudah dipahami dalam sebuah panduan secara keseluruhan; 3) Stand alone, madul yang dibuat tidak bertumputerhadap media yang lain; 4) Adaptif, mempunyai daya adaptif terhadap IPTEK; 5) User friendly, memenuhi kaidah keakraban dengan anak didik; 6) Konsistensi, penulisannya konsisten (Sirate \& Ramadhana, 2017).

Penelitian yang dilakukan oleh Natsir (2018) menunjukkan bahwa penggunaan panduan di kelompok B dapat mengkonversi sikap pendidik di kelompok B menjadi lebih positif. Serupa dengan penelitian sebelumnya, penelitian yang dilakukan oleh Anggraini (2016) membuktikan bahwa penggunaan panduan Berbasis Pendekatan Contextual Teaching \& Learning dengan Keterampilan Sosial Anak Usia 5-6 Tahun di kelompok B mampu mengembangkan keterampiran sosial pada anak usia dini

Panduan merupakan sebuah konsep yang terdapat dalam suatu pembelajaran. Cara mengetahui panduan yang dirancang serasi dengan indikator penyusunan atau tidak, maka diharuskansejumlah proses pengujian terhadap panduan yang telah dibuat. Terdapat enam tahapan dalam menyusun pengembangan, desain, dan validasi panduan. Keenam langkah tersebut adalah: 1) Sasaran panduan yang bersifat khusus; 2) Kesesuaian alat ukur kompetensi; 3) 
Kekhasan subjek; 4) Metode dan desain pembelajaran; 5) Experimen terhadap subjek; dan 6) Evaluasi. Validasi isi merupakan salah satutahapan dari fase keempat di atas,pengembangan dan validasi suatu panduan pembelajaran (Wulandari, 2018). Tujuan penelitian ini adalah untuk menghasilkan panduan pembelajaran untuk anak usia dini di kelompok B Taman Kanak- kanak.

\section{METODE PENELITIAN}

Jenis penelitian ini adalah jenis Penelitian dan Pengembangan. Adapun model penelitian dan pengembangan yang menjadi acuan dalam melakukan penelitian ini yaitu Model Borg dan Gall (2003) karena model ini mempunyai langkah-langkah yang dianggap paling sesuai dengan penelitian ini. Siklus pengembangan yang terdiri 10 langkah pengembangan, namun peneliti membatasi langkah tersebut hanya sampai pengembangan produk awal diantaranya: yaitu: 1). Analisis Kebutuhan 2). Penelitian awal dan pengumpulan informasi 3). Perencanaan Pengembangan 4). Pengembangan produk awal.

Analisi kevalidan yang akan dibahas adalah uji validitas isi. Panduan pembelajaran akan dinyatakan valid ketika evaluasi dari para ahli dan praktisi mengungkapkan bahwa panduan tersebut memiliki substansial teoritik yang kental serta konstan internal yg mengikat.

Adapun pengkategorian validasi dikutip dari Nurdin (2007), dapat dilihat pada tabel berikut:

Tabel 1. Pengkategorian Validasi

\begin{tabular}{lll}
\hline No & Interval & Interpretasi \\
\hline 1 & $3,5>X \geq 4$ & Sangat Valid (SV) \\
2 & $2,5 \leq \bar{X}_{<}, 5,5$ & Valid (V) \\
3 & $1,5>X \geq 2,5$ & Cukup Valid (CV) \\
4 & $1 \leq \bar{X}_{<1,5}$ & Tidak Valid (TV) \\
\hline
\end{tabular}

Sumber (Khabibah, 2006)

Berdasarkan kategori validitas sebelumnya, maka panduan permainan yang digunakan dapat dikatakan valid ketika (1) nilai rerata total $(\overline{\boldsymbol{X}})$ untuk segala aspek, sedikitnya termasuk dalam tingkatan valid, dan (2) $\boldsymbol{A}_{\boldsymbol{i}}$ untuk masing-masing aspek, paling tidaktermasuk dalam tingkatan valid.Jika diketahui tidak termasuk dalam tingkatan kevalidan sehingga secara krusial dibutuhkan adanya perubahan berdasarkan masukan yang diperoleh dari para validator atau dengan memperhatikan kembali aspek melihat kembali nilai yang kurang pada aspekaspek tersebut.

Tugas berikutnya adalah menghitung reliabilitas lembar penilaian perangkat dengan menggunakan hasil modifikasi rumus Percentage of Agreements Grinnel. Azwar (2010) mengemukakan bahwa reliabilitas mengarah pada kekonsistenan

64 NANAEKE - Indonesian Journal of Early Childhood Education, Vol. 3, No. 2, Desember 2020 
hasil yang telah diukur, yang berarti kecermatan terhadap pengukuran. Reliabilitas wajib dilakukan oleh alat ukur. Reliabilitas adalah ketetapan dari hasil alat ukur tersebut jika diujikan baik itu diujikan dengan sampel yang berbeda atau sama, maupun pada waktu yang bersamaan atau berbeda. Sebuah alat ukur akan dikatakan baik ketika alat ukur tersebut memiliki keandalan yang tinggi, dimana besar koefisien korelasi dimulai dari angka 0,00-1,00.

\section{HASIL DAN PEMBAHASAN}

Hasil penelitian ini mengikuti susunan model Borg and Gall (2003) dalam pembuatan komposisi teknik pembelajaran dalam peneitian ini, yakni:

1. Analisis Kebutuhan. Pelaksanaan kegiatan penyusunan pedoman ini diawali dengan need assesment. Need assesment untuk mengetahui kebutuhan awal dilapangan dalam pelaksanaan peningkatan perkembangan sosial, dan bahasa anak melalui panduan permainan kontekstual. Peneliti menggambarkan dan menjelaskan bahwa dengan menerapkan pengembangan model permainan kontekstual dalam kegiatan konteks dokter, konteks guru dan anak didik, dan konteks keluarga dapat menarik perhatian anak, menambah semangat belajar anak, membentuk kreatifitas anak, dan menyenangkan dalam penggunaan media belajar di kelas. Hal tersebut yang membuat peneliti mengembangkan kegiatan permainan kontekstual dalam bentuk buku panduan permainan kontekstual.

2. Penelitian dan pengumpulan informasi. Merujuk kepada hasil analisis kebutuhan pada anak didik dan Guru dilihat dari analisis karakteristik anak, analisis tugas guru, studi literatur dan perumusan masalah di Taman Kanakkanak Buah Hati Makassar maka dianggap penting untuk melaksanakan program pengembangan permainan kontekstual bagi anak usia dini untuk meningkatkan perkembangan sosial dan bahasa anak. Oleh karena itu sangat dibutuhkan sebuah pedoman dengan jenis buku panduan adalah panduan permainan kontekstual bagi anak usia dini. Diharapkan buku panduan tersebut dapat dijadikan alat bantu bagi setiap guru dalam membantu anak meningkatkan perkembangan sosial dan bahasa anak.

3. Perencanaan Pengembangan. Perencanaan pengembangan merupakan halhal yang dipersiapkan untuk membuat buku panduan permainan kontekstual bagi anak usia dini dalam meningkatkan perkembangan sosial dan bahasa di TK adalah pemberian motivasi/stimulus kepada anak agar anak bisa lebih bersemangat untuk melanjutkan aktivitas selanjutnya dan membuat konsep panduan permainan Kontekstual, perangkat pembelajaran yang sinkron dengan permainan (RPPH, RPPM).

4. Pengembangan Produk Awal. Penyusunan produk awal dengan mendesain buku panduan permainan kontekstual, menyusun instrumen validasi dan lembar pengamatan pembelajaran. 
Validasi isi dalam penelitan ini legalisasi oleh dua orang yang ahli dibidangnya,yang manalegalisasi oleh ahli ini merupakan legalisasi awal terhadap panduan permainan yang disusun sebelumnya. Saran yang diberikan oleh para ahli akan dimanfaatkan untuk bahan rujukan untuk melakukan revisi panduan permainan.

Tabel 2. Hasil Analisis Validasi Panduan permainan

\begin{tabular}{llll}
\hline No & Aspek Penilaian & (Ai) & Ket. \\
\hline 1. & Komponen & 3.5 & Valid \\
2. & Format & 3.2 & Valid \\
3. Isi & 3.4 & Valid \\
4. Bahasa dan Tulisan & 4.0 & Valid \\
5. Ilustrasi, Tata Letak Tabel dan Gambar & 2.9 & Valid \\
6. Manfaat & 3.5 & Valid \\
Rata-rata Keseluruhan $(\overline{\boldsymbol{x}})$ & 3.46 & Valid \\
\hline
\end{tabular}

Rata-rata nilaikeseluruhan kevalidan Panduan permainan diperoleh $\overline{\boldsymbol{X}}=\mathbf{3 . 4 6}$, nilai tersebut merupakan kategori kevalidan yang ada pada rentang $2.5 \leq \overline{\boldsymbol{X}}<3.5$. Jika dilihatberdasarkan aspek ini, maka Panduan permainan kontekstual untuk anak usia dini dapat dikatakan telah tergolong dalam tingkatan kevalidan.

Gambar 1. Panduan Sebelum Direvisi

\section{EVALUASI}

Disampingmemberikan penilaian, kedua validator juga memberikan saran dan komentar untuk revisi terha dap buku pedomanmodel pemainan kontekstual bag: anak usia dini yang sedang dikembangkan. Adapun perbaikan kecil yang telah dilakukan pada pedoman model permainan kontekstual bagi anak usia dini sebagaimana disarankanoleh validator pertama a dalah menyarankan agar jenis dan ukuran huruf pada bukupedoman di rapikan agar mudah dibaca sedangkan validator kedua adalahmenyarankan menambahkan illustrasi pada buku pedoman sehingga menarik tersebut. Dan kedua saran validator yang dinyatakan maka peneliti menindaklanjuti dengan melakukan revisi sesuai saran darikedua validator dan buku pedoman sudah bisa digunakan dalam rangka proses ujicoba empirik. 
Gambar 2. Panduan Setelah Direvisi

\section{EVALUASI}

Setelak diberikan treatment, seiring dengan tindakan yang dilakukan pads indikator ketefapaian perilaku sosial sedikit demi sedikit menunjukan peningkater: sikap yang $i \mathrm{i}$ harapkan. Perolehan skor dari setiap tiga kegiatan permainsr konstekstual pada pertamuan pertama anak mulai memunctlkan sikap penilaisr perilaku sosisl hingga mencapai tahap selanjutnya terus meningkat sampai pads pertemuan ketiga terlikat peningkatan skor yang signifikan dimana anak telak mencapai kategori berkembang sesuai harapan dan barkembang sangat taik dengarn Skorrata-rata pada pertemuan pertams kegiatan konteks dokte: mencapai 3.00 , lau pada pertemran kedus kegiatan Konteks guru dan ansk nencapai skor $3.3 \mathrm{C}$ pertemuan ketiga kegiaran kontess Keluarga mencapai skor 3.70 dan pertemusr dengan hasil keseluruhan rata-rats dari setiap kegiatan permainen kontekstual dengry indikator pencapaian perilaku sosial adalah 3.32 berarti berada pada kategor: "Tinggi".

Penilaian Panduan permainan memiliki koefisien reliabilitasdenganfrekuensi Agreement $\mathrm{d}(\mathrm{A})=25$ dan frekuensi Disagreement $\mathrm{d}(\mathrm{D})=0$ sehingga menghasilkan $\mathrm{R}=1$, angka tersebut ada pada kategori $0,90<\mathrm{R} \leq 1,0$ maka tergolong dengantingkatan sangat tinggi. Jadi, ketika dilihat dari kadar nilai reliabilitasnya maka panduan permainan dapat dinyatakan reliabel. Hal tersebut menunjukkan bahwa panduan pembelajaran telah memenuhi kriteria kevalidan dan reliabilitas untuk digunakan.

Penggunaan panduan permainan akan membantu anak usia dini dalam proses belajar mengajar. Beberapa penelitian menunjukkan bahwa penggunaan panduan memberikan dampak yang positif. Penelitian yang dilakukan oleh Natsir (2018) menunjukkan bahwa penggunaan panduan permainan kontekstual dapat mengembangkan keterampilan sosial anak. Serupa dengan penelitian sebelumnya, penelitian yang dilakukan oleh Anggraini (2016) membuktikan bahwa penggunaan panduan Berbasis Pendekatan Contextual Teaching \& Learning dengan 
Keterampilan Sosial Anak Usia 5-6 Tahun di kelompok B mampu mengembangkan keterampiran sosial pada anak usia dini

\section{KESIMPULAN DAN SARAN}

Penelitian ini menghasilkan Panduan permainan kontestual untuk Anak Usia Dini. Hasil uji validitas isi memenuhi kriteria kevalidan dengan nilai yang diperoleh $\overline{\boldsymbol{X}}=\mathbf{3 . 4 6}$, nilai tersebut merupakankadar Valid yakni terlihat pada rentang $2.5 \leq \overline{\boldsymbol{X}}<$ 3.5. Hasil penilaian ahli (validator) menunjukkan bahwa panduan permainan kontekstual untuk anak usia dini, ditinjau dari keseluruhan aspek yang telah dikatakan valid, akan tetapi validator memberikan beberapa saran untu perbaikan panduan pembelajaran tersebut. Berdasarkan hasil penelitian tersebut, peneliti mengharapkan guru (pendidik), dapat memberikan pembelajaran yang menarik dan menyenangkan untuk anak agar anak tidak merasa bosan, dan penyediaan media pembelajaran yang layak pakai dan tidak membahayakan untuk anak.

\section{DAFTAR PUSTAKA}

Abdullah, M.I. (2004). Pengembangan Model Pembelajaran Anak Usia Dini pada Kelompok Bermain PSTPA. Bengkulu: Dharma wanita Bengkulu.

Anggraini, D. (2016). Eksplorasi Bermain Berbasis Pendekatan Contextual Teaching And Learning dengan Keterampilan Sosial Anak Usia 5-6 Tahun. Skripsi. Bandar Lampung: Universitas Lampung.

Azwar, S. (2010). Reliabilitas dan validitas. Yogyakarta: Pustaka Pelajar.

Borg dan Gall. (2003). Education Research. New York: Allyn and Bacon.

Depdiknas. (2004). Pedoman Pembelajaran di Taman Kanak-Kanak. Jakarta: Direktorat Jenderal Manajemen Pendidikan Dasar dan Menengah

Khabibah, S. (2006). Pembelajaran model Permainan Matematika Soal Terbuka Untuk Meningkatkan Kreativitas Siswa Sekolah Dasar. Disertasi. Tidak Dipublikasikan. Surabaya: Program Pascasarjana Universitas Negeri Surabaya.

Lasmiyati dan Harta, (2014). Pengembangan Panduan Pembelajaran Untuk Meningkatkan Pemahaman Konsep dan Minat SMP. Phytagoras: Jurnal Pendidikan Matematika, 9 (2), 161-174.

Nurdin. (2007). Model Pembelajaran Matematika yang Menumbuhkan Kemampuan Metakognitif untuk Menguasai Bahan Ajar. Disertasi. Tidak Diterbitkan. Surabaya: PPS UNESA.

Prastowo. (2012). Panduan Kreatif Membuat Bahan Ajar Inovatif. Yogyakarta: Diva

68 NANAEKE - Indonesian Journal of Early Childhood Education, Vol. 3, No. 2, Desember 2020 
Press.

Sirate, S.F., dan Ramadhana, R. (2017). Pengembangan Panduan Pembelajaran Berbasis Keterampilan Literasi. [online]. Tersedia: https://core.ac.uk/download/pdf/234747211.pdf, [15 Agustus 2019].

Susilana \& Riyana. (2008). Media Pembelajaran. Bandung: CV. Wacana Prima

Wulandari, N.Y., (2018). Uji Validasi Isi Panduan Psikoedukasi Tutorial Membaca Permulaan Untuk Guru Sekolah Dasar. Insight, 20 (1), 42-50. 